\title{
Belphégor
}

\section{From Penny Dreadful to Graphic Novel: Alan Moore and Kevin O'Neill's Genealogy of Comics in The League of Extraordinary Gentlemen}

\section{Jeff Thoss}

\section{OpenEdition}

\section{Journals}

Electronic version

URL: http://journals.openedition.org/belphegor/624

DOI: 10.4000/belphegor.624

ISSN: 1499-7185

Publisher

LPCM

\section{Electronic reference}

Jeff Thoss, «From Penny Dreadful to Graphic Novel: Alan Moore and Kevin O'Neill's Genealogy of Comics in The League of Extraordinary Gentlemen », Belphégor [Online], 13-1 | 2015, Online since 02 June 2015, connection on 30 April 2019. URL : http://journals.openedition.org/belphegor/624 ; DOI : 10.4000/belphegor.624

This text was automatically generated on 30 April 2019.

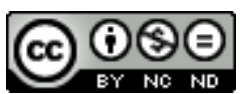

Belphégor est mis à disposition selon les termes de la Licence Creative Commons Attribution - Pas d'Utilisation Commerciale - Pas de Modification 4.0 International. 


\title{
From Penny Dreadful to Graphic Novel: Alan Moore and Kevin O'Neill's Genealogy of Comics in The League of Extraordinary Gentlemen ${ }^{1}$
}

\author{
Jeff Thoss
}

In 1890, British media mogul Alfred Harmsworth launched the halfpenny comic magazine. By reducing the page size and opting for the cheapest paper and ink, Harmsworth was able to undersell his competitors' penny-priced output and created a publishing success that was widely imitated and ushered in the age of comics as a mass medium (Sabin, Adult 21). In 2002, DC Comics started its series of Absolute Editions, which reprint popular titles that originally appeared as pamphlets in oversized hardcover books (complete with dust jacket, slipcase, and ribbon) that cost between $\$ 50$ and $\$ 100$. Evidently, something has changed in the way that comics are produced and marketed, and one may well surmise that this change of formats is linked to the change in cultural status they have experienced in the past few decades. At the turn of the twentieth century, comics "came at or near the bottom [...] in the pantheon of [...] literature" (21), a judgment of taste that finds its material equivalent in their disposable nature. At the beginning of the twenty-first century, comic books-especially deluxe editions like DC's Absolute series-are more likely to find themselves displayed in a bookcase than placed in the dustbin. And, with Art Spiegelman's Maus (1986-1991) winning a Pulitzer Prize in 1992 or Alan Moore and Dave Gibbons's Watchmen (1987) being included in Time magazine's 2005 list of the "All-TIME 100 Novels," their position in the pantheon has clearly been revised. Yet interestingly, Maus and Watchmen only received these accolades after they had been repackaged as graphic novels, both having previously been published in magazine or pamphlet format. To tell the story of comics' establishment as a "legitimate" art form is, among other things, also to tell the story of their shifting publication formats. 
2 In this essay, I propose to look at the curious evolution of comics through the lens of a series that harks back to the late-Victorian media landscape that British comics emerged from and that simultaneously embodies and questions the current state of the medium. Alan Moore and Kevin O'Neill's The League of Extraordinary Gentlemen (1999-) relates the adventures of a superhero team made up of characters from nineteenth-century classics, such as Mina Murray from Bram Stoker's Dracula (1897) and Allan Quatermain from H. Rider Raggard's King Solomon's Mines (1885). In the first volume (1999), they face Sherlock Holmes's archenemy Professor Moriarty along with a "yellow peril" in London's East End. The second volume (2003) restages the Martian invasion from H.G. Wells's The War of the Worlds (1898), after which the series moves on to the twentieth century. These early parts squarely fit into what has come to be known as Neo-Victorian fiction (Heilmann and Llewellyn, Sadoff and Kucich) and offer the typical exploitation of popular character archetypes and narrative tropes along with a revision of nineteenth-century attitudes towards race, class, and gender. ${ }^{2}$ In addition, Moore and O'Neill explore the material (pre)history of their own medium and, especially in the paratexts of their work, refer to Victorian print media, such as illustrated newspapers, novels, penny dreadfuls, boys' weeklies, and of course comics. ${ }^{3}$ The result is a playful pastiche - understood here as a not overtly parodic imitation and collage - of nineteenth-century literature, a sort of game where readers are invited to spot the references, as well as a rewrite of comics history that highlights and perhaps also resurrects comics' affinities with a largely paraliterary tradition yet also strives to transcend any division between highbrow and lowbrow. In disrespecting the border between individual texts, League also disrespects the border between venerated classic and half-forgotten trash and invites its readers to imagine a genealogy of comics that encompasses James Malcolm Rymer's penny dreadful Varney the Vampire (1845-47) as easily as Aubrey Beardsley's illustrations to Oscar Wilde's Salomé (1894).

3 As good Neo-Victorians, Moore and O'Neill reinterpret the past mainly to negotiate the present. League was published after the watershed of Maus and Watchmen and its forays into the nineteenth century can only be read against recent developments in comics. Its conception of a tradition that disregards distinctions between high and low can also be seen as a direct reaction against a contemporary historiography that all too readily describes how comics metamorphosed from disposable children's magazines into proper books and a mature art form at some point in the mid-eighties. ${ }^{4}$ Yet, paradoxically, League might very well be the new type of comic Spiegelman and Moore himself seemingly paved the way for a decade earlier. With its numerous and often obscure allusions to nineteenth-century culture in both text and image as well as its sustained reflection on comics history, it is a textbook example of an ambitious and demanding comic, its extensive reworking of the historically popular becoming - once again, paradoxically - a hallmark of its sophistication. Occasionally, it appears that Moore and O'Neill's book is not so much a continuation of their earlier work in the superhero genre but rather in line with the literary trend of historiographic metafiction, as exemplified by Neo-Victorian novels such as John Fowles's The French Lieutenant's Woman (1969) or A.S. Byatt's Possession (1990). In any case, League ennobles the medium of comics via strategies such as selfreflexivity, intertextuality and the creation of a tradition at the same time as it problematizes this ennoblement. And, of course, League has been repackaged from its original pamphlets and published as a graphic novel (both in hardcover and paperback) and even been given the deluxe treatment of an Absolute Edition by DC. In this last 
version, the first two volumes of Moore and O'Neill's work retail for $\$ 75$ each. In the following paragraphs, I will explore the workings and implications of this $\$ 150$ comic that takes us back to the age when comic papers and related print forms proudly advertised " $1 \mathrm{~d}$ " or even " $1 / 2 \mathrm{~d}$ " on their front pages.

Figure 1

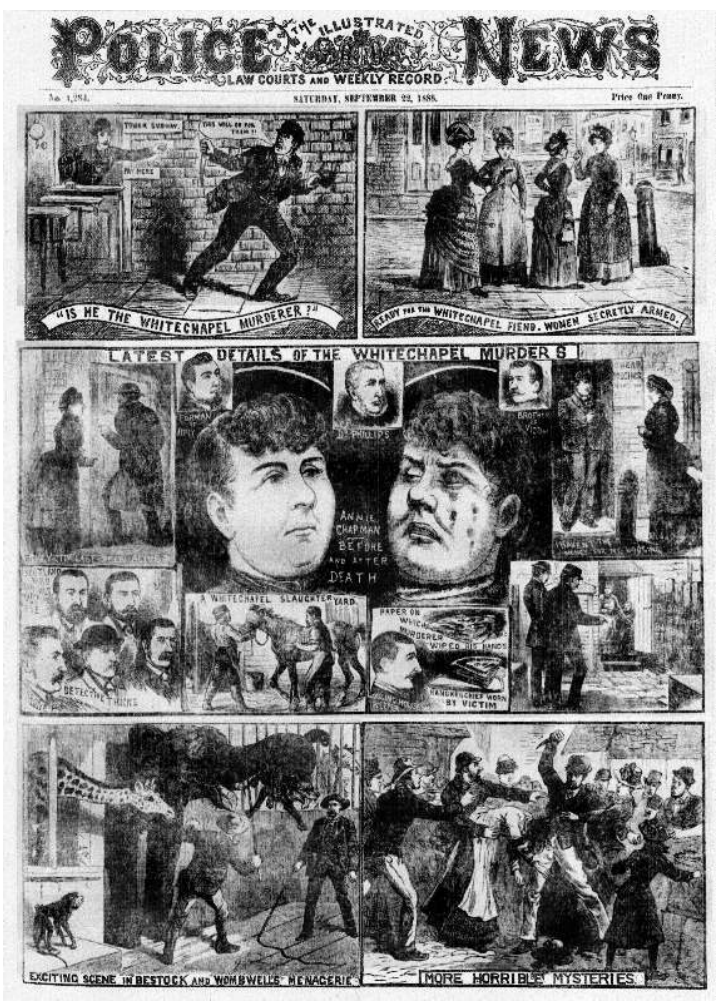

Front page of The Illustrated Police News, 22 September 1888

Such front pages are, in fact, present in League, and one of the main features of nineteenth-century print media that Moore and O'Neill quote and imitate. The cover to volume 1 , issue 1 , for instance, is modelled after an illustrated newspaper, a format initiated by the Illustrated London News in 1842 (see League 1:178). ${ }^{5}$ Jess Nevins, who has compiled companion books containing detailed annotations to League and upon whose invaluable work I will draw more than once in this essay, specifically lists the Illustrated Police News (see Figure 1), which became notorious for their coverage of the Ripper murders, as an influence (Heroes 110). In any case, the cover, with its lurid headlines "Ghastly Murderer Stalks Paris Fleshpots" (1: 178) - and drawings of half-clad women, generally recalls the sensationalism associated with this type of publication. In keeping with the spirit, League does not announce itself as a comic but as a "grand new picture paper" at the top of the page. As a matter of fact, Moore and O'Neill go to great lengths to prevent the term "comic" (as well as "graphic novel") from appearing anywhere. In the authors' biographical notes on the back cover of the first volume, Alan Moore is introduced as writer of chapbooks and penny dreadfuls ("produced with the younger reader in mind"), while Kevin O'Neill is presented as a pictorial satirist and illustrator, famed for producing works such as the "Queen Victoria and Emily Pankhurst Girl-on-Girl Novelty Flipbook." Elsewhere, one finds expressions such as "picture-periodical" or "comical narrative" $(1: 5,4)$, and an advertisement for volume 1 at the end of volume 2 
highlights its "coloured cover and plates" (224), as if it were an illustrated Victorian novel or penny dreadful.

5 According to Kevin Carpenter, the term "comics" came into regular use around 1890 (61), and the OED lists its earliest appearance as 1889 ("Comic"), so its use would not have been anachronistic. Still, it may have had too modern connotations to go well with Moore and O'Neill's project of fashioning themselves as Victorian artists. What is more important, though, is that the terms that are used in its stead neatly allow the creators to link comics to, and locate them within, a field of other media that combine text and image or use pictures to tell stories. Despite an often ironic undertone, League's historiography does not present penny dreadfuls, illustrated newspapers and flipbooks as historical curiosities or embarrassments, as Victorian ephemera that were thankfully displaced by the arrival of the proper format of comics. Rather, they are made out to have been an integral part of the formation of comics and are thus accorded their place in the medium's tradition. Moore and O'Neill are actually in line with noted comics historians here: Roger Sabin sees the origin of British comics in illustrated newspapers, penny dreadfuls, boys' weeklies (on which more later) and cartoon magazines (Comics 12-14), a perspective also adopted by the British Library's 2014 exhibition "Comics Unmasked: Art and Anarchy in the UK" (Gravett and Dunning); David Kunzle's two-volume History of the Comic Strip even goes back as far as late-medieval broadsheets. Yet League not only emphasizes the continuity between Victorian comics and earlier media; the terminological anxiety displayed by Moore and O'Neill is reminiscent of that surrounding "graphic novel" nowadays, and one can detect numerous contemporary resonances in the authors' dealings with the nineteenth century. To modern readers, League indirectly seems to plead that the term "graphic novel" will not displace "comics" and that the however questionable emergence of mature and sophisticated comics will not silence a long history of childish, sleazy and cheap comics. 
Figure 2

Our New Sensational Story: WANTEDI $\& 1,000$ REWARD. See page 2.
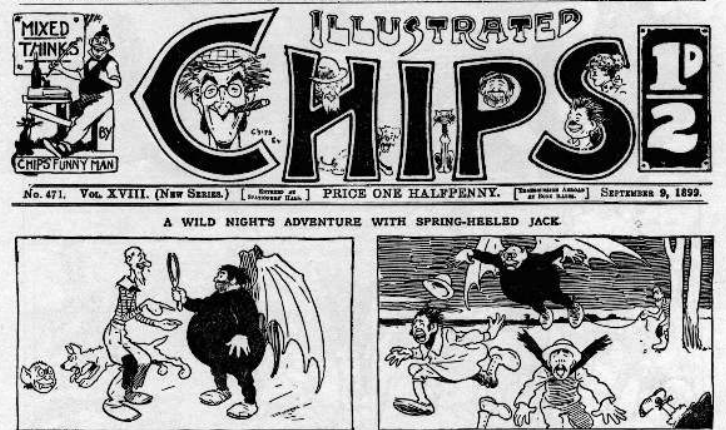

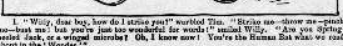
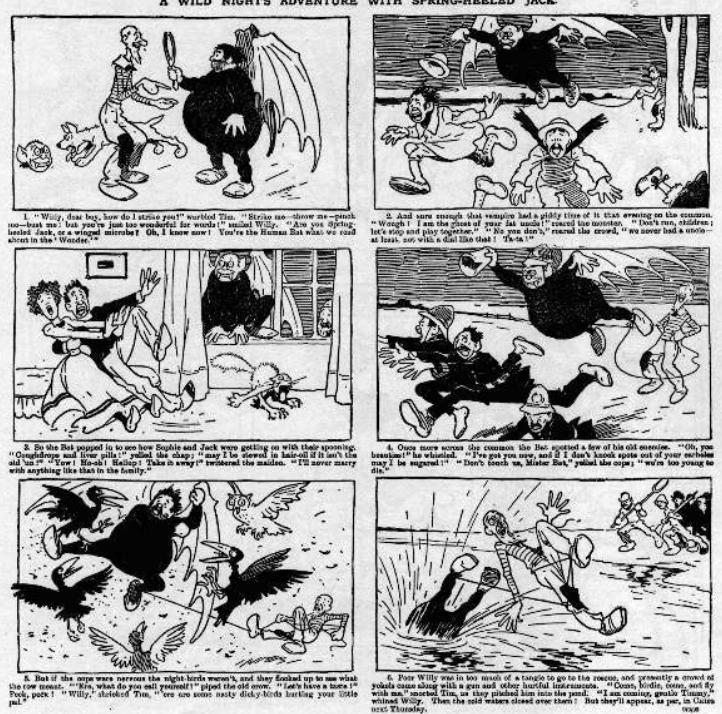

Front page of Illustrated Chips, 9 September 1899

The issue covers of League, volume 1, continue to masquerade as Victorian printed matter. For instance, the second one features cigarette cards of the series' protagonists, the cigarette brand being "Blue Dwarf", the name of a popular penny dreadful character. On the cover to issue 4 , the title is printed in thick black letters on an orange background, below which is reproduced a sketch of a majestic Mr. Hyde raising his fist against a group of stereotypical Chinese villains. According to Kevin O'Neill, this reflects the look of "early Arsène Lupin publications" (qtd. in Nevins, Heroes 118), but its pulp-magazine quality is evident even beyond this specific source. Issue 5 is done, again in the artist's own words, "[i]n the style of [a] late Victorian book cover, the sort that had [an] image printed on [a] cloth bound cover and an inset full colour image pasted on" (118-19). This cover is of note since the authors mostly quote the material features of decidedly lowbrow publications targeted at the working classes and here introduce respectable, middle-class culture. Yet this only serves the series' aim of questioning these categories, of imagining an alternative history in which these distinctions never existed, in which comics could as easily be accepted as descendants of the penny dreadful as they could be seen in a novelistic, book-focused storytelling tradition. It is with the cover to volume 1's closing issue that League finally imitates its most recognizable antecedent: the comic paper. Flaunting a large title banner at the top followed by a grid of six rectangular panels with cartoonish drawings and narration underneath, this layout is based upon the front page of comics such as Illustrated Chips or Comic Cuts (Harmsworth's revolutionary halfpenny publications; see Figure 2 and League 1:184). There is even a period-appropriate advertisement (for cigarettes) in the page header. 
7 In all these cases, there is an obvious discrepancy between what readers are actually holding in their hands and what the cover design suggests or announces that they are holding. Even issue 6's cover does not constitute comics as we know them; the lack of speech bubbles in late-Victorian comics is immediately palpable. As Christine Ferguson notes, Moore and o'Neill here "perform what we might term a Brechtian move, forcing readers to confront the political implication of the genre's form instead of allowing them simply to immerse themselves in plot" (202). Whereas comic book covers generally function as straightforward gateways into the storyworld, League's covers first seem to ask its audience "What does this have to do with comics?" And, in a way, the answer is always : "This also is comics." Each issue requires that readers establish a connection and see the similarities and mutual interactions between what is now known as comics and whatever medium the cover has disguised itself as, be it a trashy tabloid or a cloth-bound classic.

This strategy of crosslinking and merging supposedly distinct cultural forms is also what characterizes Moore and O'Neill's pastiche narrative. The main characters and plot elements are almost exclusively lifted from familiar classics by the likes of Wells, Stevenson, Verne, or Conan Doyle, but this may be more of a pragmatic rather than an aesthetic choice. After all, most characters or storylines from Victorian paraliterature have been forgotten; arguably, even Sweeney Todd's fame is based upon a musical and its film adaptation rather than a penny dreadful. However, in the realm of supporting or minor characters, one can find such people as Rosa Coote, a staple of Victorian pornography, Broad Arrow Jack from the eponymous penny dreadful, or Alley Sloper, the "first true British comic strip hero" (Gifford 7). The series' creators are also not afraid to reference works that have not nearly had the impact on contemporary popular culture as the above-mentioned authors, which is shown by the inclusion of Anthony Trollope's Plantagenet Palliser as Prime Minister.

If League's cover design continually reminds readers to draw connections between different publication formats, then its handling of characters invites them to disregard such distinctions altogether. And, of course, unless one reads Nevins's companion books alongside or looks up names on the Internet, one is unlikely to spot all the allusions and detect, for instance, that there is something fishy in Broad Arrow Jack serving aboard Captain Nemo's Nautilus. Still, one always knows that the whole narrative has been cobbled together from already existing narratives, even if one cannot pinpoint the exact sources, and this combination of a lingering general awareness and a blissful ignorance of the details might contribute to the pleasure of reading League. One may even view Moore and O'Neill's practice of borrowing everything as a kind of covert homage to the rampant "borrowing" that went on in the comics of the 1890s. As Kunzle observes, "the whole phenomenon of cheap comic papers in England depended from their inception on the availability of foreign sources which could be plagiarized at will and without fear of legal repercussion" (2: 333). In any case, League fantasizes about a world in which a character's origin in this or that publication format, whether it be a respectable novel or an erotica magazine, has lost all relevance and anything can be combined. ${ }^{6}$ As Alan Moore himself describes the aim of the series, it is about "having fun by pulling down the barriers between High Literature and pulp literature and pornography and low literary forms like that" (qtd. in Nevins, Blazing 254). 
Figure 3

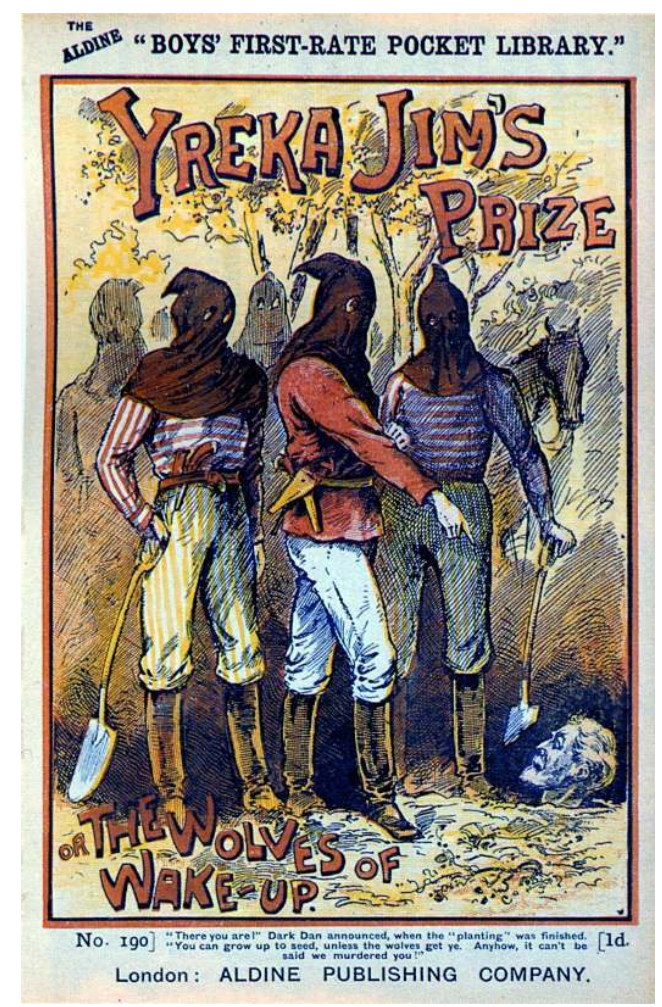

Cover of Boys' First-Rate Pocket Library no. 190, ca. 1890s

Perhaps League's most ingenious mix of literary forms and most intriguing material feature is the existence of an illustrated prose narrative that is appended to the first volume. Its title is Allan and the Sundered Veil, and it purports to be the first issue of a boys' weekly called The "Boy's First-Rate Pocket Library" of Complete Tales, which sells for the regular one penny. ${ }^{7}$ All of this information can be gleaned from its cover, which naturally looks very much like a boys' magazine cover (see Figure 3 and League 1:153). The publisher is listed as "Aldine Publishing Co." and the next page features an advertisement for The Rival, another Aldine title. Nevins's research shows that the advertisement is authentic and that the publisher and magazine, which reprinted American dime novels, did indeed exist (Heroes 98-99). It looks as if form and content finally matched, as if Moore and O'Neill had come full circle and included a pseudo-facsimile of the kind of publication that served as League's inspiration. Appearances are once again deceiving, however, as Allan and the Sundered Veil, which functions as a prequel to the events of volume 1, is by no means a straightforward pulp affair. While the narrative does draw upon pulp stalwarts Edgar Rice Burroughs and H.P. Lovecraft, it also incorporates material from the more respectable Haggard and Wells. Still, what is most striking is that the story is written in a "rococo, lush, and over-ripe style" (99) that is especially fond of describing the decay of luxurious objects (e.g.: "magnificent Axminster carpets annexed long since by the creep of moss and slug and fungus", 1: 155). As Nevins points out, this is a "deliberate recreation of the style of fin-de-siècle, Yellow Nineties Decadent writers [...], as if one of them had written a boys' magazine story" (Heroes 99).

Basically, then, Allan and the Sundered Veil fuses The Boy's First-Rate Pocket Library and The Yellow Book, creating an strange matrimony between two publication formats that could 
not be further apart: on the one hand, the penny-prized boys' weekly that does not even contain original material; on the other hand, the five-shilling literary quarterly that features contributions by avant-garde artists and writers. Moore and O'Neill thus take what one might see as the endpoints of the lowbrow-highbrow scale and tie a knot between them, inciting their readers to reflect on the merit of this dichotomy at the same time as they provide an example of a text that seems to have already surpassed it. This technique is succinctly summed up in an item that also finds itself at the back of League, volume 1: a "painting-by-numbers" version of Basil Hallward's portrait of Dorian Gray, "produced," as the instructions inform us, "with children or the amateur painter in mind" (1: 186). Here, the aesthete and the amateur meet, and the icon of late-Victorian Decadence is turned into lowbrow kitsch, art for those who have neither the necessary skill nor taste to engage with art, just as the unique, auratic artwork is transformed into a mass-produced commodity. Yet note that the painting-by-numbers portrait is not presented as some defacement or travesty of the actual painting by ignorant brutes, but as Hallward's own invention. It is he who "envisions" this "innovative painting-madesimple concept" (1:186) and thus comes to represent the union of high and low Moore and O'Neill aim for, the fictional artist of the fin-de-siècle becoming a model for the real artists of today. Finally, the hybrid material composition of League, volume 1, which contains a "regular" comic book, an illustrated prose story, and miscellaneous visual material such as the portrait, also indicates that the comics tradition the authors have in mind encompasses more than what a standard definition of the medium might allow for.

Yet, for all its attempts to level distinctions between popular and elite culture and rewrite the history of comics as inclusive, as spanning a wide range of pictorial and narrative traditions as well as publication formats, League is, of course, still affected by the way mainstream comics are produced, distributed, and consumed nowadays. As with any successful series, its single issues are collected into graphic novels encompassing a single story arc, and, as already mentioned, it also takes part in the recent trend of releasing comics in formats that have more in common with expensive art books than flimsy magazines. In order to fully characterize the vantage point from which Moore and O'Neill look back to the nineteenth century, I would like to return briefly to that crucial period of the mid-1980s, when the decision to repackage comics as graphic novels apparently flicked a switch in the general public's perception of them.

Longer comics published in book format have existed at least since the 1970s, and continental Europe has a long tradition of reprinting stories from magazines or newspapers in albums, yet in the English-speaking world, it was only when the "Big Three" - Maus, Watchmen, and Frank Miller's Batman: The Dark Knight Returns (1987) appeared that the status of comics was revised in any significant way. Suddenly, comics reached a larger audience since they were no longer mainly sold by specialist fan-shops but also in high-street bookstores, they were bought by public libraries, they were reviewed in the mainstream press, and mainstream book publishers took interest in them (Sabin, Comics 165). (To this, one could add that it is also only with Maus that comics regularly found their way into schools and universities.) The sea change that took place is pithily demonstrated by Sabin's quote from a fan-shop owner who claims that "in the old days" he occasionally "had to put comics in brown paper bags like pornography," whereas "the new book format seemed to short-circuit that psychological barrier" (Adult 94). 
14 It must be stressed that none of the "Big Three" were originally conceived as graphic novels, and while Art Spiegelman actively sought to reprint the Maus stories from $R A W$ magazine in book format, ${ }^{8}$ it seems unlikely that $\mathrm{DC}$, the publisher of the other two and a company that is notorious for its disdain of creators' rights, gave Moore or Miller much say in the way that their comics were to be marketed and distributed. Nevertheless, the simple fact that one could suddenly read exactly the same story in a traditional book that one could previously read only in pamphlets seemingly made all the difference. While there was a backlash against the graphic-novel hype, this period nonetheless marked "the transition of part of the comics industry from a 'comics culture' to a 'book culture"' and "rema[d]e comics in prose literature's image" (247). Roger Sabin made this statement in 1993, and, in the intervening years, this transition can only be said to have accelerated and taken in larger parts of the industry (even though the emergence of webcomics and digital comics has obviously also shifted part of the attention onto this sector).

Moore and O'Neill's obsession with the ephemera of yesteryear is clearly a reaction against this process in which comics have lost their disposable nature. However, theirs is not a nostalgic look back to an age of innocence, of simple stories and crude pictures. To those critics who declare 1987 to have been the annus mirabilis that saw the birth of comics as a true art form, the League series replies that this can only have been the result of their myopic perspective and that comics have always had more to offer than they were given credit for. And yet, one cannot look past the fact that League is evidently a comic that has to a considerable extent remade itself in the image of prose literature, that comes, if one so desires, in an expensive, prestigious, and collectible format, and that demands quite a lot from its readers if they are to be fully let in on the game being played. There are times when it appears that Moore and O'Neill's work is in some ways a rather highbrow enterprise that caters to an exclusive readership in its very attempt to be as inclusive as possible.

According to Nevins,

the series sold surprisingly well, with higher sales than a number of industry mainstays. In trade paperback form League's sales are very high, and the comic has been translated into several languages and is sold in 30 countries. Beyond mere sales, however, the series has proven to be popular with audiences beyond ordinary buyers of comic books. A significant number of fans of League are men and women who don't buy other comic books, including authors, editors, literature students and literature professors. (Heroes 15-16)

17 There are two things of interest here: one is League's success as a graphic novel - Moore himself concurs that "in bookshops it is probably the best selling graphic novel" (qtd. in Nevins, Blazing 271) - the other is its popularity with the audience Nevins describes. Although Nevins does not explicitly state this, one might be tempted to see a correlation between the two and assume it to be more likely that this larger readership buys the League graphic novels in a bookshop rather than hunting down single issues in specialist shops. Of course, there is nothing wrong with a comic attracting a wider audience that prefers to buy books. Yet one may suspect that Moore and O'Neill's creation appeals precisely to the authors, editors, literature students and professors Nevins so conspicuously singles out because these people possess an education that greatly facilitates the appreciation of League, so that they get the most of out of it. I have mentioned earlier that, for its most significant characters and themes, the series draws upon literary classics that have become part of popular culture. One may not have read Dracula, King Solomon's Mines, the Sherlock Holmes stories, The War of the Worlds, or Vingt 
mille lieues sous les mers (1870), yet these texts are still familiar through their countless adaptations. In many other cases, one may notice that some text is being alluded to without knowing precisely which text it is. League thus ensures that a basic degree of recognizability always exists, which allows its readers to more or less pass over the allusions they do not get. In fact, one could doubt whether the comic would have had the kind of success Nevins and Moore describe if this were not so.

Nevertheless, in a comic that consists of nothing but references to other texts, spotting these references is an integral part of the reading experience, and there are moments when Moore and O'Neill's "reference mania" appears bent on causing frustration, when it seems as if the comic will not let us in on a joke because our knowledge of nineteenthcentury (para-) literature is simply not vast enough. How many readers are familiar enough with Victorian illustrated newspapers to actually identify them as the source for the cover to issue 1 or realize that the representation of Mars at the beginning of volume 2 conflates Edgar Rice Burroughs's Barsoom stories, Edwin Lester Arnold's Lieutenant Gullivar Jones: His Vacation (1905), C.S. Lewis's Out of the Silent Planet (1938), and Wells's War of the Worlds? Evidently, League is catering to a small coterie of readers with such obscure allusions, a coterie to whom the identification of such details provides an additional (or even the main) gratification. At first sight, this might not appear very different from similar practices within mainstream comics, as when superhero titles appeal to their readers' detailed knowledge of continuity (the shared history of a particular publisher's characters and fictional universe). However, what sets Moore and O'Neill's enterprise apart is its obvious tryst with literary history. Sebastian Domsch has noted that League's boundless intertextuality in this regard may represent a disturbing, even "monstrous and unnatural" element to a comics audience that regards Literature as "alien" (103), while Moore himself has described League as "this complex literary joke that is probably about a lot of books that they [comic readers] haven't read and would never be interested in reading" (qtd. in Nevins, Blazing 259). Should one construe this to mean that the series was indeed meant to bypass a core comics readership and explicitly target authors, editors, literature students and professors? If Moore and o'Neill created their comics genealogy for the sole benefit of an audience that ordinarily does not buy comics and were not interested in whether traditional comics readers would like to know more about the texts or media they construct this genealogy from, would League then not defeat its own purpose?

Luckily, for those not in the know there are Jess Nevins's companion books, in which one can always look up the origin of some particular element. The existence of these guides is in itself worthy to be commented upon, though. Philip E. Wegner, in an essay on the "modernism of the graphic novel," associates Nevins's books with the guides that have appeared to James Joyce's Ulysses (1922) or Thomas Pynchon's Gravity's Rainbow (1973), "some of [League's] most important modernist and postmodernist print predecessors." I am not sure to what extent this is a compliment and to what extent it surreptitiously places League in a tradition of notoriously "difficult" books, books so evidently in need of explanation that regular recourse to a guidebook seems necessary. Similarly, the "modernism of the graphic novel" might in this case conjure up a rather negative image of modernism as hermetic and elitist, as an art that consciously shuns and spurns the accessibility and immediate gratification of popular culture.

If all of this does not seem to apply to League, then a discussion of the end of volume 2 may redress this situation. So far, I have not drawn upon the second volume as much as 
the first one because it largely follows its example and is not quite as heavily invested in historical print culture and materiality as the first book..$^{9}$ (Volume 2, for instance, features a uniform cover design that, albeit indubitably retro, is light on specific allusions.) However, there is one feature that stands out: The New Traveler's Almanac, a mock-Victorian tour guide that is appended to the main story in much the same way that Allan and the Sundered Veil is in the first book. The Almanac essentially describes a world in which the endless amount of fictional places authors have dreamed up in the course of literary history are real and coexist on the same planet. As to the number of literary references Moore and O'Neill make in it, suffice it to say that for the 50-page Almanac there are 127 pages worth of annotations in Nevins's companion book. Recognizing and identifying these allusions appears to be the main draw of this section of League, as it provides a matter-of-fact survey with little in the way of plot, characters, dialogue, etc. One could see the Almanac as a kind of supplement, an additional offer for the abovementioned coterie that others may simply skip. Yet, as if they were trying to penalize readers for doing so, the authors have hidden a crucial plot element in it: Allan Quatermain and Mina Murray, by now the series' protagonists, become immortal, a fact that is continuously alluded to in subsequent volumes - which have so far traced their adventures up to the early twenty-first century - yet never explicitly explained again.

The Almanac definitely constitutes a virtuoso display of intertextuality that would shame any modernist or postmodernist writer, a grandiose attempt to create a storyworld that contains all other storyworlds - including the one of Jorge Luis Borges's "El Aleph" (1945) - yet it will surely also strike some as more than a little self-indulgent, as a random cannibalization of all the texts of the past perhaps, to paraphrase Fredric Jameson's famous critique of postmodernism (65-66). Here, Moore and O'Neill are heaping references upon references without integrating them into the kind of accessible and riveting narrative they cared for elsewhere. The plot point about Allan and Mina gaining immortality constitutes something akin to the ultimate reward for those who have followed the authors' lead to the end, but few beyond the diehard fans of intertextuality, who approach the Almanac equipped with Nevins' guidebook or an Internet connection close by, may actually have been willing to do so. Labelling League as difficult or elitist or inaccessible may, in these sections, no longer seem to be entirely unjustified, and one may argue that the comic here overshoots its mark in its attempts to ennoble the medium, expediting rather than questioning the division between the new, sophisticated graphic novels and the old, humble comics.

22 League has been described as "a kind of recycling plant, turning elements of old popular fiction into new popular fiction" (Sulmicki), but in view of what I have just said, one may perhaps also view it as turning old popular culture into new high culture. In reflecting on the history of comics and the various publication forms that have shaped it, in reworking Victorian (para-) literature into highly self-conscious narratives, Moore and O'Neill are producing a work that shows all the marks of high culture and attracts an audience that is familiar with historiographic metafiction, Neo-Victorianism or other varieties of postmodernist fiction. One can hardly blame the creators for the existence of graphicnovel and deluxe editions of their work ; this is standard industry practice. Moore, in fact, has in the past been quite vocal about his opposition to the term "graphic novel," denouncing it as a mere marketing ploy that "just came to mean "expensive comic book" and, through its inflationary use, "tended to destroy any progress that comics might have made in the mid-' 80 s" ("Interview"). Still, the graphic novel seems to be a format that is 
perfectly suited to the new kind of audience League addresses, which would not otherwise buy comics. And clearly, League is most rewarding to readers who come equipped with a decent knowledge of nineteenth-century literature and who are willing to invest in the companion books (early versions of which can be accessed online) or read up on characters, texts, and Victorian print media they were unaware of elsewhere.

And yet, League is not something akin to the "Waste Land" of comics. It is also about a team of superheroes, even if they are unusual superheroes, it participates in mainstream comics' long tradition of crossovers between fictional universes, and it belongs to the popular genre of steampunk as much as it belongs to the perhaps more literary phenomenon of Neo-Victorianism. The series may be most gratifying to a coterie, yet this coterie may be composed of Victorianists willing to tackle what appear to be modern children's magazines, comic readers unafraid of forays into Literature as well as those who have always been in-between. Moore and O'Neill continuously straddle the line between lowbrow and highbrow, and while their work may occasional appear as too complex for its own sake, they always know what is currently at stake in comics. If the graphic novel is not to become detached from the rest of comics' history, if it is not to be perceived as the legitimate and respectable counterpart to the trashy and trivial comic pamphlets, then its connection to that history must be emphasized and partly excavated. The paradox of producing an expensive, cloth-bound book that praises cheap magazines printed on paper so brittle that the magazines would disintegrate even if they were not thrown away cannot be avoided, but it can be explored and discussed within that book itself. If the various pictorial and storytelling traditions that have existed since Victorian times are to be kept alive, then the best method of doing this might just be to engage in a balancing act and write a sophisticated graphic novel that demonstrates how even in the most sophisticated graphic novel there is a trace of the penny dreadful - and vice versa.

\section{BIBLIOGRAPHY}

Barker, Martin. Comics, Ideology, Power and the Critics. Manchester: Manchester UP, 1989. Print.

Boehm-Schnitker, Nadine, and Susanne Gruss. "Introduction: Spectacles and Things - Visual and Material Culture and/in Neo-Victorianism." Neo-Victorian Studies 4.2 (2011): 1-23. Web. 19

September 2012.

Carpenter, Kevin. Vom Penny Dreadful zum Comic: Englische Jugendzeitschriften, Heftchen und Comics von 1855 bis zur Gegenwart. Oldenburg: Bibliotheks- und Informationssystem der Universität Oldenburg, 1981. Print.

“Comic.” OED Online. September 2012. OUP. Web. 18 September 2012.

Domsch, Sebastian. "Monsters against Empire: The Poetics and Politics of Neo-Victorian Metafiction in The League of Extraordinary Gentlemen." Neo-Victorian Gothic: Horror, Violence and Degeneration in the Re-Imagined Nineteenth Century. Ed. Marie-Luise Kohlke and Christian Gutleben. Amsterdam: Rodopi, 2012. 97-121. 
Ferguson, Christine. "Steam Punk and the Visualization of the Victorian: Teaching Alan Moore's The League of Extraordinary Gentlemen and From Hell." Teaching the Graphic Novel. Ed. Stephen E. Tabachnick. New York: MLA, 2009. Print.

Gifford, Denis. Victorian Comics. London: Allen \& Unwin, 1976. Print.

Gravett, Paul, and John Harris Dunning. Comics Unmasked: Art and Anarchy in the UK. London: British Library, 2014.

Heilmann, Ann, and Mark Llewellyn. Neo-Victorianism: The Victorians in the Twenty-First Century, 1999-2009. Basingstoke: Palgrave Macmillan, 2010. Print.

Jameson, Fredric. "Postmodernism, or The Cultural Logic of Late Capitalism." New Left Review 146 (1984): 53-92. Print.

Kunzle, David. History of the Comic Strip, vol. 1: The Early Comic Strip. Narrative Strips and Picture Stories in the European Broadsheet ca. 1450-1825. Berkeley: U of California P, 1973. Print.

Kunzle, David. History of the Comic Strip, vol. 2.: The Nineteenth Century. Berkeley: U of California P, 1990. Print.

Moore, Alan. “The Alan Moore Interview.” By Barry Kavanagh. Blather. 17 October 2000. Web. 26 September 2012.

Moore, Alan, and Kevin O'Neill. The League of Extraordinary Gentlemen, vol. 1. La Jolla : DC ComicsWildstorm, 1999. Print.

Moore, Alan, and Kevin O'Neill. The League of Extraordinary Gentlemen, vol. 2. La Jolla : DC ComicsWildstorm, 2003. Print.

Nevins, Jess. Heroes \& Monsters: The Unofficial Companion to The League of Extraordinary Gentlemen. Austin: MonkeyBrain, 2003. Print.

Nevins, Jess. A Blazing World: The Unofficial Companion to The League of Extraordinary Gentlemen, Volume Two. Austin: MonkeyBrain, 2004. Print.

Sabin, Roger. Adult Comics: An Introduction. London: Routledge, 1993. Print.

Sabin, Roger. Comics, Comix \& Graphic Novels: A History of Comic Art. London: Phaidon, 1996. Print.

Sadoff, Dianne F., and John Kucich. "Introduction: Histories of the Present." Victorian Afterlife:

Postmodern Culture Rewrites the Nineteenth Century. Ed. John Kucich and Dianne F. Sadoff.

Minneapolis: U of Minneapolis P, 2000. ix-xxx. Print.

Spiegelman, Art. MetaMaus : A Look Inside a Modern Classics, Maus. New York: Pantheon, 2011. Print. Sulmicki, Maciej. "The Author as Antiquarian: Selling Victorian Culture to Readers of NeoVictorian Novels and Steampunk Comics." Otherness: Essays and Studies 2.1 (2011). Web. 19 September 2012.

Wegner, Philip E. “Alan Moore, 'Secondary Literacy,' and the Modernism of the Graphic Novel.” ImageTexT 5.3 (2010). Web. 10 September 2012.

Witek, Joseph. “Imagetext, or, Why Art Spiegelman Doesn't Draw Comics.” ImageTexT 1.1 (2004). Web. 26 September 2012. 


\section{NOTES}

1. I would like to thank Bernhard Metz for instigating this essay and Judith Brand, Andreas Mahler as well as the members of the Berliner Comic-Kolloquium for helpful comments on earlier versions of it.

2. For a reading of League that focuses heavily on these aspects, see Domsch.

3. Neo-Victorianism's frequent engagement with material culture is lengthily discussed by Boehm-Schnitker and Gruss.

4. Roger Sabin writes that "[o]vernight, it was claimed, comics had developed from cheap throwaway children's fare to expensive album-form 'novels' for adults to keep on bookshelves" ( Adult 235). Joseph Witek nicely illustrates this by showing how early reviewers of Maus emphasized its newness to the point of denying that Spiegelman had anything to do with comics and their previous history, leading one critic to produce "the rather perplexing line, "Art Spiegelman doesn't draw comics."”

5. In my discussion of League, I will be referring to the trade paperback (aka graphic novel) edition of the two volumes, the most widely available version. While it regrettably omits some of the original pamphlets' paratexts, such as mock-Victorian tables of contents, advertisements, and letter pages, it also introduces some new material that is of use to my argument. Originally, both volumes are unpaginated; page references follow the pagination established by Nevins ( Heroes and Blazing). Due to copyright restrictions, I am unfortunately unable to reproduce material from League. The cover illustrations can, however, be found on the Grand Comics Database: http://www.comics.org/series/7064/covers

6. This has taken on a new significance in some of the later installments that take place in the twentieth century. The existence of international copyright laws, which one cannot simply ignore as one could in late-Victorian times, has here led the creators to mask the identity of characters they have, for example, borrowed from the James Bond or Harry Potter franchise.

7. Boys' weeklies were supposed to offer a "'wholesome' alternative" to the dreadfuls' sensationalism and questionable morality (Sabin, Comics 14). In practice, though, there was considerable overlap between the two (Carpenter 13-14), so that Allan and the Sundered Veil may just as well be read in the context of the penny dreadful. The association of comics with the dreadfuls is perhaps stronger because both were massively campaigned against for being an alleged threat to youth, which in the case of comics led to a ban on certain genres and subject matter from the 1950s to the 1980s (Barker 99).

8. MetaMaus, the deluxe edition of Maus, contains Spiegelman's rejection letters from publishers.

9. Print culture and materiality would, however, return with a vengeance in the 1950s-themed third book, The League of Extraordinary Gentlemen: Black Dossier (2007). As always, Moore and O'Neill show great care in mixing high and popular culture, as the third book contains, among other things, imitations of British children's comics, such as The Beano and The Dandy, a Tijuana bible produced in the world of 1984, and a pulp novel written in the style of the Beat Generation. There is also a section in 3D (glasses are included), and the book was initially supposed to contain a vinyl recording as well as postcards, which testifies to Moore and O'Neill's desire to probe the material limits of the graphic novel format. Subsequent installments have once again been more subdued in this regard, though. 